\title{
Contributions of Islamic scholars to sustainable human and environmental development: Islam Hadhari and future development of Muslim countries
}

\author{
Ibrahim Olatunde Uthman*, L.O. Abbas and \\ K.K. Oloso
}

Department of Arabic and Islamic Studies, Faculty of Arts, University of Ibadan (UI), Ibadan, Oyo Sate, Nigeria

E-mail: ibrahimuthman@yahoo.com

E-mail: latabs03@yahoo.com

E-mail:kkoloso@yahoo.com

*Corresponding author

\begin{abstract}
Today, despite the global scientific and technological advancement with developed and even a few developing countries including Muslim countries making significant strides in shaping contemporary civilisation and the state of the world, yet they have failed to achieve true development and progress on how to sustain human and other creatures in a wholesome manner. This is because while these countries are struggling for scientific and technological development in order for humans to live a decent and comfortable life, they have not fully comprehended the underlying indexes that formed the basis of sustainable development. This paper therefore examines the teachings of Islam on the underlying indexes that formed the basis of sustainable development. It used the maqasid approach to show that in Islam development and progress are useful and desirable only when they improve upon and sustain not only human comfort and standards of living but also the essentials to achieving higher and enhanced quality of life for not only humans but also the environment and all the creatures cohabiting in it. It finally reveals how the maqasid approach in Islam sets out to achieve this real development.
\end{abstract}

Keywords: component; Islam; technological advancement; maqasid; human development.

Reference to this paper should be made as follows: Uthman, I.O., Abbas, L.O. and Oloso, K.K. (2011) 'Contributions of Islamic scholars to sustainable human and environmental development: Islam Hadhari and future development of Muslim countries', Int. J. Arab Culture, Management and Sustainable Development, Vol. 2, No. 1, pp.17-29.

Biographical notes: Ibrahim Olatunde Uthman holds a $\mathrm{PhD}$ in Usul al-Din and Comparative Religion from the International Islamic University, Malaysia. He is a Lecturer of Islamic Studies at the University of Ibadanand. He is currently the Department PG Coordinator and Convener/Secretary of the 2012 International Conference on Arabic/Islamic Studies. He has taught at the universities in Nigeria and Malaysia. He has published in American Journal of Islamic Social Sciences (2010), Islamic Studies (2010), IKIM Journal of Islam and International Affairs (2006), Journal of Islam in Asia (2005) and the Journal of Religion and Culture, (2000 and 2001). He was a Consultant in the writing of The Mapping of the Global Muslim Population. 
L.O. Abbas is a Senior Lecturer at the Department of Arabic and Islamic Studies of the University of Ibadan, Nigeria. He obtained his BA (Hons) in Arabic Language and Literature, MA in Arabic and Islamic studies and $\mathrm{PhD}$ in Islamic Studies all from the University of Ibadan specialising in Imamship and Islamic Institutions. He worked briefly, after his first degree, as a Producer at a state television and thereafter joined the teaching profession at the higher institutions. He teaches Islamic Law (Shari'ah) and jurisprudence.

Kamil Koyejo Oloso is a Senior Lecturer of Islamic Studies, University of Ibadan, Nigeria. He obtained his $\mathrm{PhD}$ in Islamic Studies from the university which is on Haj Institution and teaches Islamic Law. He has published in several scholarly journals, including Journal of Oriental and African and Studies (JOAS), Al-Fikr: Journal of Arabic and Islamic Studies, Ibadan Journal of Humanistic Studies, Journal of the Department of Religious, University of Ilorin (JARS), and Ado Journal of Religion (University of Ado Ekiti). He is currently the Head of Islamic Studies unit at the Department of Arabic and Islamic Studies, University of Ibadan.

\section{Introduction}

Though there is tremendous global scientific and technological advancement recorded by developed and even a few developing countries including Muslim countries like Malaysia in contemporary human civilisation, nevertheless, the world has failed to achieve true development and progress among its human community not to talk of other non-human inhabitants of the universe. This paper argues that the prevailing degrading state of the world is because while most humans desire to live a decent and comfortable life, they have not fully comprehended the underlying indexes that formed the basis of sustainable development. I therefore proceed to examine the teachings of Islam on sustainable development using the maqasid approach to show that in Islam development and progress are useful and desirable only when they improve upon and sustain not only human comfort and standards of living but also the essentials to achieving higher and enhanced quality of life for not only humans but also the environment and all the creatures cohabiting in it. I will also demonstrate how a modern Muslim country is employing its Islam Hadhari approach to achieve this real development in contemporary society. I begin the exploration on sustainable development by analysing the concepts of development, progress, and renaissance as explained by Martin Lings (2005). ${ }^{1}$

The analysis will be a good starting point on the examination of Islam and sustainable development. This is because Martin Lings' exposition revolves round a major keyword of the subject matter of this paper, development. It becomes more relevant because his exposition on development from the Islamic perspective was given at a public lecture delivered at Al-Azhar University in Cairo in the Arabic language. Martin Lings defines development as moving away from the principles, and this movement according to him is a prerequisite for development and progress though the movement must not deviate too much or too far from the principles.

To Lings, every individual in this life hopes to attain development or progress and a Muslim is not exempted as she/he pleads for progress when praying, yet communities, and I do emphasise here that Muslim communities in particular, do not progress and are in fact stagnating today despite their aspirations and constant prayers. This happens 
because these communities have refused to move away from Islamic principles and transform these principles into platforms for progress or have moved completely away from these principles as we see in many Muslim societies today (Lings, 2005).

When this happens according to Lings, the hope of human communities in attaining development and Muslim communities in particular lies in renewal, which he conceives as the opposite of development since it is about a restoration of something of the primordial purity and vibrancy of Islam. Therefore, for Muslims, renewal that brings real development and progress is a movement that is predicated on the return of the way of the Prophet (SAW), his companions and those who followed in their footsteps and any movement that negates the principles of Divine guidance embodied in the Holy Book and the way of the Prophet Muhammad, (SAW), is not development or progress, but degeneration from the Islamic perspective

Bearing in mind the necessity for Muslims to stick to the principles of divine guidance embodied in the Holy Book and the way of the Prophet Muhammad, (SAW), in order for them to achieve development, Lings warned against using the term renaissance for this renewal as is commonly used synonymously for the term Tajdid or Islah in place of renewal because of its un-Islamic connotations with the European Renaissance that was also a renewal but of the ancient pagan Greece and Rome. This pagan renewal or European Renaissance that has enthusiastically been taken up by Muslim countries from the West without making the slightest discrimination between its pagan implications and Islamic teachings brought an end to the traditional Christian civilisation and heralded the prevailing modern materialistic world, promoting the centrality of money and worldly possessions while antagonistically thwarting or distorting the expression of the spiritual, religious and Godly (Lings, 2005).

Here lies the problem of modern development as (I) will argue in this paper. It is the failure to fully comprehend the materialistic focus of European Renaissance that is responsible for today's human material development at the expense of sustainable development. The main feature of this materialistic outlook is maximisation of profits, hedonism and exploitation. Development is seen as the ever-increasing accumulation of material and mundane benefits and warding off of artificially created harmful scientific inventions.

Eckersley laments the negative spiritual impact of the above materialism when combined with individualism. It leads to the complete separation of material benefits from spiritual development, consumerism from true happiness and proliferation of artificial needs from human preservation. What follows then is the perversion of religion which negates any beneficial effect of materialism, freeing the individual from social regulations, and resulting in deviations and compromises within religion, including a greater tolerance of consumerism and self gratifications, thus removing any need to choose between God and mammon (Eckersley, 2007). Thus today's human development is as a result of humans having happily chosen mammon (Eckersley, 2007).

Consequently, in the wake of striving for progress and development, Muslim countries that are today aping the West today in their attempt to also develop and progress materially at the expense of Islamic principles are missing the essence of sustainable development from the Islamic perspectives. By seeking development and progress through embracing the West and using western categories and standards to measure what is permissible and prohibited (al-haläl wal-harām), they have also failed to correct the lopsided western understanding of development. (I) therefore define sustainable development as progress that is not only focused on humans but also 
non-humans, not only focused on material and economic wellbeing but also spiritual, psychological and intellectual advancement. To achieve this, (I) argue here that Muslim scholars and countries must move closer to the Islamic principles of al-haläl wal-harām as encapsulated in the maqasid for humanity to attain true development. This is what distinguished Islamic civilisation, which reached its zenith during Europe's middle Ages, from its European counterpart and this is what can set humanity back on the path of sustainable development.

\section{Islam, human and revealed knowledge for sustainable development}

In the above Islamic civilisation as in its western contemporary counterpart, knowledge is the bedrock of development. The importance of knowledge as a vital asset to both spiritual and material development has been repeatedly emphasised in Islam. No wonder Islam teaches that Muslims must embrace the acquisition of knowledge as a religious obligation. This obligation is not limited to religious knowledge alone both also human innovative, scientific, physical and technological knowledge. Both types of knowledge concerning the human psyche, society, the universe, and nature constitute holistic sources of guidance. Many Qur'anic passages such as (Q96: 1-5, 3:190-91, 10:1, 12:1, 13:1, $15: 1$, and 30:20-25) refer to both revealed and acquired knowledge as the signs of Allah that must be taken and understood together if humanity is to be successful on Earth. In fact, the first passage constitute the first commandment revealed to the Prophet (SAW) and it is instructive that even at the initial stage in his mission, he was not only commanded to seek knowledge but also knowledge of human creation in particular.

The Sunnah is also replete of many incidents that confirm that the signs found in the divine laws governing creation must be understood in order uncover these laws. For instance, the Prophet used knowledge acquired through observation, experiment, and experience as source of religious and secular guidance when he observed Ibn Sayyad, a Jewish youth, to understand his unusual character and to ascertain if he was indeed the Antichrist. In fact, in this particular case the Prophet can be regarded as having employed what we now consider the prerogatives of experimental psychology, psychiatry, and other paramedical sciences related to the study of human nature. Only when people take the initiative, according to these and other passages, to change their natural states through their knowledge of the universe predicated on revelation can they ascend from one state of civilisation to another (11:13 and 84:16-19) (Uthman, 2010).

\section{Muslim contribution to civilisation}

Despite today's backwardness of Muslims generally and their conspicuous insignificant contribution to the shaping of the prevailing civilisation in a sustainable wholesome manner, Muslims once served as the precursors and torchbearers of the scientific knowledge that culminated in today's modern civilisation, as can be seen in the following sections. 


\subsection{Muslims and scientific development}

The remarkable achievements made by Muslims in the medieval period, as noted by Bernard Lewis, shook Europe out of its centuries-long slumber. According to D.N. Dunlop, these scholars' contributions to modern education began appearing in Europe during the tenth century, and by the thirteen century their works in almost all branches of knowledge could be found throughout Europe. Known as wise men, they were patronised by the caliphs because they were true universal scholars who had mastered many physical, natural, human, and revealed sciences. They were also guided by ethical considerations, the very ones that are missing from the development of contemporary scientific, engineering, biomedical, financial, and other disciplines. One result of this absence has been numerous man-made problems. As suggested by Mohamad Shamsher, since "ethical behavior is not inherited but must be instilled and nurtured through systematic training programmes that must be implemented consistently in the most objective way", the failure of the current educational system at the global level calls for an in-depth investigation as to why it produces professionals an experts who, despite having not imbibed the 'character' or 'discipline' of their educational curriculum, are nevertheless awarded degrees for having been found "worthy in both learning and character" or 'knowledge and discipline' (Uthman, 2010).

Given the above, the remainder of my article will now examine some of the principles guiding sustainable development in Islam. After this, it discusses sustainable development, the ecosystem and the consequences of the absence of sustainable development in today's materialistic civilisation. It will then look at the maqasid approach in Islamic and how it has informed the Malaysian Islam Hadhari approach of achieving sustainable development in contemporary society:

\subsection{Islamic philosophy of sustainable development}

- It is useful here to examine the Islamic philosophy of sustainable development and see whether this can be re-enacted in today's society. The real difference between sustainable development and the prevailing development lies in their goals, epistemological foundations, principles, and philosophies.

- Islam states that Allah created human beings as his representatives to work for the sustainable development of the universe, their ummah (community), and other ummahs. All of these creatures use the ecosystem like human beings, since they constitute ummahs in their own right (6:38). Thus each Muslim is responsible for the sustainable use and cultivation of the ecosystem. This responsibility is not limited only to humanity's benefit, for it is also a right of all other members of creation. Thus the Prophet commands Muslims to sustain growth even if they can see no benefits coming from such actions. As one prophetic hadith states, when the Day of Judgment comes, the person who has a palm shoot in his/her hand should plant it, and whoever brings a piece of dead land to life will receive a reward. The proper use of natural resources (e.g., water, land, trees, and air), as well as the proper disposition and utilisation of the benefits from animals, plants, birds, insects, fish, and other mammals in the ecosystem, is therefore a religious obligation. 
- Hence, John Esposito concludes that Islam's view of human responsibility is cosmic in proportion and that, as a result, people will be judged on the cosmic consequences of their actions (Uthman, 2010).

\subsection{Sustainable development and the ecosystem}

All of the ecosystem's natural resources and creatures contribute to nature's growth in one way or another. For instance, the soil or the land that Allah has laid down (55:10) is undoubtedly a source of life for everything and everyone. For instance, water is not only pure and an agent of purification, it is also a source of life for dead land and a drink for animals (25:48-50 and 80:24-32). It is the same with air, which is both pure and an agent of purification, as well as a source of life for all living things (15:22) and the movement of clouds (7:57). It is noteworthy that the Prophet forbids urinating in stagnant water, a well, along a path, in a shaded area, or in a dwelling. Based on what has been said above, humanity is duty-bound to work for the sustainable development of all natural, human, and non-human resources and to ensure that none of them is degraded, wasted, or exploited. In short, Islam enjoins the type of sustainable development that can be attained only when people move beyond physical and material development in order to include moral and ethical development. This means that material advancement must not be just an end in itself; rather, realising and promoting moral and ethical values in all material and physical development must be humanity's fundamental objective when it comes to using and exploring nature's resources. The rejection or neglect of this philosophy, upon which Islamic science is based, has precipitated the ongoing crisis, chaos, and suffering in the world despite our scientific and technological advancement. This is where Islam can help modern man to achieve sustainable development and progress and thereby stop the degradation, destruction, and exploitation of the environment, natural resources, and other constituents of biodiversity.

\subsection{Consequences of unsustainable development}

That each component that makes up the ecosystem, both its inanimate natural resources and other living creatures contribute to nature's growth in one way or another can be seen from the benefits that accrue even from painful occurrences such as natural disturbances, which are erroneously depicted by some disaster analysts as 'wicked' disasters. These disturbances, aside from alleviating the hunger and thirst of all creatures and endowing the universe with the capability to sustain human, non-human, and all other constituents of the universe's needs, do not equal the death toll from man-made disasters.

Even such occurrences as death, a divine natural means of maintaining balance in the world, that arise from these natural disturbances, do not equal the death toll from manmade disasters. When human beings tamper with the natural means of put in place for maintaining balance in the world and the sustainability of all beings, catastrophic disasters of unimaginable magnitude are inflicted on the entire environment and its differing and teeming communities. This can be seen in the fact that such man-made disturbances as war, weapons of mass destruction, toxic waste, pollution, disease, global warming, desertification, soil degradation, and erosion are now gradually destroying the ecosystem's equilibrium. The emergence of modern technology and industrialisation marked the beginning of the modern era's ecological problems. The inventions of science have made war, a potent medium of earth degradation, even more horrible 
and destructive, as the atomic bombing of Hiroshima and Nagasaki made clear (Uthman, 2010).

This unwholesome development for the entire biosphere is the fallout of the absence of Islamic principles of what is permitted and what is prohibited in human renaissance for development and progress. These unwholesome developments include the immoral disasters caused by the ethical corruption of human beings. Such immoral occurrences include the failure of large financial corporations that result in huge financial losses and the erosion of public confidence in the financial system. The immoral disasters that have rocked the financial markets have led to the death of many hardworking people, some of whom have lost their life savings. These entire human made disasters have called the nature of contemporary society's development and progress into question. Hence, there is a serious need for a new direction and orientation towards sustainable development in all its ramifications.

\section{Muslims and future sustainable development: using the Islam Hadhari approach based on the maqasid scheme}

In the remaining sections (I) will now use the maqasid approach to assess how Malaysia which propounded the Islam Hadhari approach for reenacting Islamic civilisation is using Islamic contents and messages on sustainable development to achieve a progressive Islamic civilisation in contemporary society.

\subsection{The maqasid approach}

The analysis of the maqasid (ultimate objectives) approach in the Islamic Laws shows that it revolves round a scheme of benefits and harms (masalihah and mafasid) and postulates that the Islamic Law is aimed at protecting five ultimate objectives. These objectives are religion, life, intellect, offspring and property. In short, the maqasid is designed so that both worldly and religious, physical and spiritual and mundane and celestial enjoyment are acquired by humanity. What accrues in terms of benefits or ward off in terms of harms (for example, supplying food among the need to benefit the hungry and healing the sick to ward off diseases) is however predicated on both real and potential benefits and harms and not merely on material gains and profits. This scheme is therefore guided by the underlying rationale, goal and intention as well the subsequent effect and impact on humans, non-humans, the environment and the global community.

There are many Islamic maxims that guide the maqasid scheme in Islam. The first is the maxim: al-asl fi al-ashya al-Ibahah ma lam yarid dalil al-tahrim or al-asl fi al-ashya al-Ibahah hatta yadulla al-dalil ala al-tahrim which means that the original rulings on things is their permissibility as long as there is no evidence that proves their prohibition. This entails the permissibility of accruing all benefits and warding off all harms unless there is evidence in the two absolute frame works of Islam (The Qur'an and Sunnah) that prohibits accruing such benefits and warding off such harms. Another two related legal maxims are: al-darar yuzal which means that harm should be alleviated and dar' al-mafasid awla min jalbi al- masalih which means warding off harm has precedence over accruing benefits. On the basis of these two legal maxims, Muslim scholars like al-Suyuti emphasise that if the intended benefits and harms are contending, then warding off the 
intended harms is is of higher priority as the Lawgiver is more preoccupied with what $\mathrm{He}$ has forbidden than with He has commanded (Jalal, 2004).

Furthermore, in the maqasid scheme, the intended benefits and harms are those established by the Islamic law in accordance its above five ultimate objectives such as freedom of religion, right to life and dignity. Hence al-Ghazali, the great Shafi'iy scholar argues that the considered juristic benefits or harms as the case maybe must be those intended by the Lawgiver and not those designed by human beings. He therefore differentiated between the ultimate objectives and purposes set by Allah, the Lawgiver and not those decided on the basis of human whims and caprices. Any imaginary benefit which is prohibited by the Islamic Law for example is mulghat or null and void and must be discarded (Al-Ghazali, $1322 \mathrm{AH}$ ).

So also is the case of any benefit that does not originate from the maqasid scheme either in its restricted or unrestricted form (maslaha al-mursalah), such benefit according to hence Al-Ghazali would be unaccepted because it does not qualify as a darurah or necessity that meets any of the above five ultimate objectives on the essential level. It is also not a definitive benefit whose realisation is certain and its benefit is not universal or meets the needs of a community (Al-Ghazali, $1322 \mathrm{AH}$ ). This is also the views of scholars like Imam al-Shatibi who pioneered the field of maqasid scheme as an independent field of Islamic Law. As matter of fact, the maqasid scheme requires that the ultimate fundamental objectives, values and ethical considerations of the Islamic Law must never be neglected in human actions especially those directed at development and progress. While Muslim scholars like al-Shatibi disagree on which of these five necessary and essential values (al-darurah al-Khamsah) or five the ultimate fundamental objectives have the highest priority or precedence. Is it religion and in this case Islam that has priority over life or is it life that has priority over religion? Nonetheless, Islamic scholars are unanimous that all the above ultimate fundamental objectives originate from the Islamic absolute reference frameworks, qualify as darurat or necessities on the essential level and are all definitive benefits whose realisation are certain and whose benefits are universal or meet the needs of the entire global community (Al-Ghazali, $1322 \mathrm{AH}$ ).

Based on this unanimity of Islamic scholars, it is correct to argue that the indexes of sustainable development from the Islamic perspective as argued in this paper would include the preservation of all religious, socio-economic, political and intellectual institutions such as the institutions of mosque administration, Islamic law implementation, collection and distribution of zakah, waqf and sadaqat, good governance and primary, secondary and tertiary education that guarantee not only human right to life but more importantly to qualitative living, religious freedom, material comfort, dignity, reproduction and intellectual capacity. From the analysis of sustainable development using the maqasid approach, all the above would constitute the indexes to measure sustainable development in Islam.

Indeed the above indexes are the parameters used in formulating and conceiving what is now known as the Islam Hadhari approach postulated by the former Prime Minister of Islamic Malaysia to make human capital development the most important to be invested upon in order to re-enact the glorious Islamic Civilisation of the past. How modern nation states like Islamic Malaysia can appropriate these rich aspects of Islamic civilisation to produce a fully holistic human, social, economic, intellectual, moral, political and in fact integrative national development is relevant to this paper because of the composition of Malaysia as a multi lingual, cultural and religious society with an estimated $60.4 \%$ Muslim majority population. Malaysia historically is known in local parlance as Tanah 
Melayu and was originally inhabited by Malay Hindus. These Malay original settlers were converted to Islam collectively during the Malacca sultanate between 14th and 15th century and have since remained the dominant Muslim and racial community in the country. Though while the Malay Muslims have always been in the majority from the inception of the country during the same the Malacca sultanate, there were influxes of both Chinese and Indian non-Muslim communities into the country. The Chinese and Indian non-Muslim communities came mainly as trade merchants as Malacca was an entry port for foreign merchants (Jen-T'chiang, 2007).

However, it was the colonial era that afforded more Chinese and Indians the opportunity later to enter Malacca and due to the British colonial free trade policy as well as availability of massive work in tin mining, rubber and other commercial sectors. This made it possible for the British colonialists to practise a divide and rule policy between Muslims and non-Muslims. Due to the British divide and rule policy between Muslims and non-Muslims, Malaysians were identified based on their races geographical locations and jobs specialisations. While the original Malay settlers were mainly farmers living in the rural areas, the Chinese were tin miners living in the urban areas and the Indians were rubber tapers living in rubber plantations. The British divide and rule policy eventually created a wedge between the races as well as Muslims and non-Muslims (Jen-T'chiang, 2007).

Consequently, long standing prejudices and biases have since existed among Muslims and non-Muslims in Malaysia and have created serious barriers social interaction and cooperation between them. For instance while the Malay Muslims look at the non-Muslims as shylock business magnates who control the Malaysian economy unscrupulously, the non-Muslims perceive the Malay as lazy Muslims who maltreat their female folk and control the Malaysian politics using Islamic sentiments and prejudices (Jen-T'chiang, 2007). This perception of Malay Muslims by non-Muslims is further strengthened by the special rights given to Malay Muslims by the Malaysian Federal Constitution to bridge the educational and economic imbalance between them and non-Muslims. These rights include the adoption of the Malay language as the official national language while the non-Muslims and other races were however allowed to preserve their cultures and languages in their own schools as long as the Malay language is made compulsory, land reservation for Malays, the creation of the position of the Yang Di Pertuan Agong to safeguard the above special rights of Malays by reserving for them positions in the public service, scholarships and other similar privileges, accorded by the Federal Government (Jen-T'chiang, 2007).

Though the idea of using the Malay language as the official national language and medium of instruction in all national schools was aimed at uniting all races in the country, it failed to bridge the gap between the non-Muslim and Muslim Malay communities as many non-Muslims especially the Chinese saw the policy as way of gradually making them to lose their language, culture and identity. The introduction of the new economic policy (NEP) from 1970 to 1990 that granted Malays 30\% equity in all economic, commercial and industrial operations in the country, also widened the gaps between Muslims and non-Muslims. Conversely, the development is believed to have contributed to increasing interaction and interdependence between Muslims and non-Muslims in general and Malays and Chinese in particular (Jen-T'chiang, 2007).

It is paradoxical despite its multicultural and religious stability and harmony, Malaysia is a country that is today regarded as a model for a modern Islamic state. The whole world was shocked when in 2001; the then Prime Minister, Dr. Mahathir 
Mohamad boldly declared that Malaysia was an Islamic country. It is even more shocking that Muslim women who are usually portrayed as backward and oppressed by a patriarchal Islam and therefore need to be emancipated are in fact playing a leading role in all sectors of the 'Islamic Malaysian' Society. This is because by the late '90s, many leading scholars had come to terms with the projection of the country as an Islamic state (Uthman, 2009). How the country is grasping with the concept of modernity and Islam, especially as it affects Muslim women and how it has used its Islam Hadhari approach to mobilise its citizenry especially the Malays for development and progress; will be of immense benefit to the global community.

\subsection{Using the Islam Hadhari approach of Islamic Malaysia}

The Islam Hadhari approach was launched by the former Prime Minister of Malaysia, Abdullah Ahmad Badawi in 2003 to propel the development and progress of the country and indeed the entire Muslim world on the basis of Islamic principles which he summarised into ten namely: Faith and piety in Allah, a just and trustworthy government, a free and independent people, a vigorous pursuit of knowledge, balanced and comprehensive economic development, a good quality of life for the people, the protection of the rights of minority groups and women, cultural and moral integrity, the safeguarding of natural resources and the environment and strong defence capabilities. This approached was enunciated by him to fulfil the Islamic aim of a developing both human and natural capital of a society in a wholesome and holistic manner. In his capacity as both the Prime Minister of Malaysia and the Chairman of the Organization of Islamic Countries, Ahmad Badawi promoted Islam Hadhari approach throughout his regime to the whole world and Muslim countries in particular. The approach as seen in the contributions of Muslim scholars to civilisation in the past, stresses the role of knowledge in the achievement of economic advancement, alleviation of poverty and the total emancipation of the Muslim world.

The approach calls for self-assessment and evaluation (muhasabah) to gauge the strengths and weaknesses of Muslims. It stresses the use of reason and rationale in resolving disputes based on Qur'anic injunctions (Q16:125 and 41:34). It recalls the Hudaibiyah Agreement signed by the Prophet Muhammad (SAW) with the non-Muslims of Makkah as a sterling example to the principle that war and the use of force are not the surest shortcut to success. Islam Hadhari is in short a means of renewal (tajdid) to revert the Ummah back to its fundamental principles and basics as prescribed in the two absolute sources of Islam and that were used to establish the past Islamic civilisation. It dictates the concept of life as service to God, work as worship, humans as vicegerents of Allah and the obligation to seek strength in every aspect of life. It teaches a change in attitude that requires ijtihad and a broader understanding of jihad as encapsulating all aspects of life such as the pursuit of knowledge, mastery of science and technology, economic prosperity, drive to seek quality (Itqan), vision of a global civilisation, spirit of brotherhood and sisterhood (ukhuwah Islamiah) and Islamic culture that balances the needs of this world and the next, fardhu kifayah and fardhu ain based on the statement of Allah to seek the home of the hereafter without forgetting the 'lawful enjoyment' in this world (Q28: 77) (Badawi, 2007).

The last principle underscores the bane of the prevailing western civilisation and its materialistic development. It has failed to balance its craze for worldly enjoyment with what is lawful and beneficial to the whole universe including humans and non-humans. It 
is only when human economic advancement is predicated on 'lawful enjoyment' in this world (Q28: 77) that it can lead to sustainable development and be devoid of crimes, sins, oppression, tyranny, mischief and corruption ( $f a s a d$ ) against human and non-human beings.

\subsection{Relevance to global challenges}

According to Islam Hadhari, one of the global challenges facing the Muslim world in the course of reenacting Islamic civilisation is the acquisition of knowledge as a vital asset to material development. As can be seen in the gross domestic product (GDP) of (OECD) economies, more than $50 \%$ of their GDP is based on the production and distribution of knowledge. In the case of the US economy for example, its economic output is roughly the same in terms of tons as it was a century ago but its real economic value has doubled 20 times over because it a knowledge-based economy. Hence, there is need for Muslim countries to make their people their greatest resource and asset by enhancing their human capital. For instance, a country must have sufficient human capital whether to build and develop industries, fix machines or make investment in technology.

This human capital can only be build through heavy investment in research and development, formal education, training, on the job learning and lifelong learning. However the Muslim world is far from achieving this as in 2004, only the United Arab Emirates in the Arab World was ranked 16 on the World Economic Growth Index, five other countries were ranked 28 and below while the remaining Arab countries were not on the index yet two-third of the world's oil supply comes from them. That lack of human capital development is responsible for the year's Arab World on the World Economic Growth Index is confirmed by Arab Human Development Report in 2003 which described the Arab World educational system as characterised by outdated curricula, unqualified teachers, substandard facilities and inefficient institutions and policies. The Arab World's lack of familiarity with the English language, which is true of most Muslim countries including Malaysia, has been mooted as a militating factor against their exposure to human knowledge.

The above dismal description of the human development in the Muslim world is worsened by the fact that Muslim women, who constitutes almost $50 \%$ of the population of the Muslim World are still generally struggling to have unhindered access to education and contribute fully their own quota to the economy of their countries. The Muslim countries that have made tremendous strides in this area include Bahrain, the United Arab Emirates and Malaysia (Badawi, 2007).

Events in the Arab World, especially Tunisia, Egypt and Libya in the months of December 2010 and March 2011 have confirmed the need for the Muslim World to develop and improve upon the conditions of living of the people in a holistic manner. According to news reports, especially by the BBC News on Africa, unprecedented street demonstrations and protests against the failure of government over the years as characterised by lack of employment, price hikes and public corruption, have sent shock waves throughout the Middle East region. The Arab world has been transfixed by the recent dramatic events in Egypt and Tunisia. Popular street protests have swept across these countries, forcing the stepping down of Husni Mubarak, just days after similar protests saw Tunisia's President Zine al-Abidine Ben Ali flee his country. Open defiance of the authorities and calls for these leaders to stand down forced them to eventually vacate their positions. Could a domino effect sweep more leaders from power, starting 
from Colonel Gadaffi, the Libyan strongman as it did around Eastern Europe in 1989 asked the BBC? Below are the social indicators in some Arab countries and the faces of some of its rulers that could be swept away in the nearest future.

The above troubled situation in the Muslim world makes the Islam Hadhari approach of Islamic Malaysia more relevant today. For the Arab world not to crumple or collapse, it is time they emulated the Malaysian example in re-enacting Islamic civilisation. In the case of Malaysia, the country is heavily investing in critical areas of pre-primary, primary and tertiary education, critical thinking and innovative skills, knowledge of critical languages especially the English language, science and technology and information and communication technology. The country is also providing women adequate access to education and representation in both political and economic decision-making process. In fact, women already outnumber men in Malaysian institutions of higher learning (Badawi, 2007). Malaysia is committed through the above human capital development efforts to reenact the past Islamic civilisations because it believes that the past glorious age of Islam was not only characterised by faith and piety to Allah (SWT) alone but also by pervasive knowledge and learning, university scholarship and ubiquitous innovation and discoveries. Through the above Islam Hadhari approach, the former Prime Minister, Badawi, used the powerful religious imperative and compulsion to act, in this case Islam, to inspire his people towards the good of humanity, progress and development, an approach that values substance and not form, sustainable progress based on Islamic values and not unbridled materialism and human capital development of just natural resources alone (Badawi, 2007).

\section{Conclusions}

The analysis of the maqasid approach in this paper shows that Islam values both human and non-human development and support development and progress that improve upon and sustain human and non-human goodness, wellbeing, comfort and standards of living as well as comfortable and enhanced quality of life for human, non-human creatures and the environment. These values such as good governance, education system and others that guarantees not only right to life but also qualitative living, religious freedom, material comfort, dignity, reproduction and intellectual capacity constitute the indexes to measure sustainable development in Islam and this what the Islam Hadhari approach sets out to achieve in terms of this real development in Islam for the citizens of Malaysia.

\section{References}

Al-Ghazali, A.H. (1322 AH) Al-Mustasfa min 'ilm al-Usul, Dar al-Qadir, 1322 AH, Vol. 1, pp.284-286, 296, Cairo.

Badawi, D.S.A.A. (2007) Islam Hadhari Approach: towards a Progressive Civilization/Selected Speeches, pp.i-308, by Dato Seri Ahmad Abdullah Prime Minister of Malaysia Malaysia, Department of Islamic Development Malaysia (JAKIM).

Eckersley, R.M. (2007) 'Culture, Spirituality, religion and health: looking at the big picture', Medical Journal of Australia, Vol. 186, pp.S54-S56.

Jalal Al-Din (2004) 'Abd al-Rahman Al-Suyuti, Al-Ashbah wa al-Nazair fi Qawa'id wa Furu al-Shafi'iyah, Dar al-Salam, Vol. 1, pp.66, p.167, p.215, Beirut. 
Jen-T'chiang, N.Z.C. (2007) 'Advocacy on 'inhumane practices'" and Roslizawati Mohd Ramly and Muhammad Khairi Mahyuddin, 'Muslims and non-Muslim relations: bridging the gap and building respect', in Ab Rahman, A. et al. (Eds.): The World Today: Current Global Issues, p.5, Universiti Sains Islam, Malaysia.

Lings, M. (2005) A return to the Spirit, pp.60-64, Fons Vitae, Louisville, KY.

Uthman, I.O. (2009) 'Muslim women in Nigeria: the position of FOMWAN and lessons Islamic Malaysia', JOAS, Journal of African and Asian Studies, Vol. 18, pp.245-265, Greece.

Uthman, I.O. (2010) 'Muslims and science: contributions of Islamic universities to professional ethics', The American Journal of Islamic Social Sciences, Vol. 27, No. 1, pp.54-74.

\section{Notes}

1 In his book which was originally a lecture that he delivered at the al-Azhar University in Cairo. 